\title{
Physical and genetic interactions of yeast Cwc21p, an ortholog of human SRm300/SRRM2, suggest a role at the catalytic center of the spliceosome
}

\author{
RICHARD J. GRAINGER, ${ }^{1}$ J. DAVID BARRASS, ${ }^{1}$ ALAIN JACQUIER, ${ }^{2}$ JEAN-CHRISTOPHE RAIN, ${ }^{3}$ \\ and JEAN D. BEGGS ${ }^{1}$ \\ ${ }^{1}$ Wellcome Trust Centre for Cell Biology, University of Edinburgh, Edinburgh, EH9 3JR, United Kingdom \\ ${ }^{2}$ Institut Pasteur, CNRS URA2171, Génétique des Interactions Macromoléculaires, 75015 Paris, France \\ ${ }^{3}$ Hybrigenics S.A., 75014 Paris, France
}

\begin{abstract}
In Saccharomyces cerevisiae, Cwc21p is a protein of unknown function that is associated with the NineTeen Complex (NTC), a group of proteins involved in activating the spliceosome to promote the pre-mRNA splicing reaction. Here, we show that Cwc21p binds directly to two key splicing factors-namely, Prp8p and Snu114p-and becomes the first NTC-related protein known to dock directly to U5 snRNP proteins. Using a combination of proteomic techniques we show that the N-terminus of Prp8p contains an intramolecular fold that is a Snu114p and Cwc21p interacting domain (SCwid). Cwc21p also binds directly to the C-terminus of Snu114p. Complementary chemical cross-linking experiments reveal reciprocal protein footprints between the interacting Prp8 and Cwc21 proteins, identifying the conserved cwf21 domain in Cwc21p as a Prp8p binding site. Genetic and functional interactions between Cwc21p and Isy1p indicate that they have related functions at or prior to the first catalytic step of splicing, and suggest that Cwc21p functions at the catalytic center of the spliceosome, possibly in response to environmental or metabolic changes. We demonstrate that SRm300, the only SR-related protein known to be at the core of human catalytic spliceosomes, is a functional ortholog of Cwc21p, also interacting directly with Prp8p and Snu114p. Thus, the function of Cwc21p is likely conserved from yeast to humans.
\end{abstract}

Keywords: protein interaction; Prp8; cwf21; Snu114; splicing

\section{INTRODUCTION}

The removal of introns from precursor-messenger RNAs (pre-mRNAs) is performed by RNA splicing, a process that is evolutionarily conserved in eukaryotes from yeast to humans. It is carried out in the nucleus by a large and highly dynamic RNA-protein complex called the spliceosome that contains over 100 proteins and five small nuclear ribonucleoprotein particles, the $\mathrm{U} 1, \mathrm{U} 2, \mathrm{U} 4, \mathrm{U} 5$, and $\mathrm{U} 6$ snRNPs (Bessonov et al. 2008; Wahl et al. 2009).

Many conformational rearrangements take place during the assembly, activation, and disassembly of the spliceosome and between the two chemical reactions. First, U1

Reprint requests to: Jean D. Beggs, Wellcome Trust Centre for Cell Biology, University of Edinburgh, King's Buildings, Mayfield Road, Edinburgh, EH9 3JR, United Kingdom; e-mail: jbeggs@ed.ac.uk; fax: 44-131-650-8650.

Article published online ahead of print. Article and publication date are at http://www.rnajournal.org/cgi/doi/10.1261/rna.1908309.
snRNP binds to the 5 'splice site on the pre-mRNA, then the ATP-dependent association of U2 snRNP at the intron branch site creates a precursor of the spliceosome referred to as A complex. Binding of the preformed U4/U6.U5 triple snRNP to the A complex creates the $\mathrm{B}$ complex, then a series of ATP-dependent structural rearrangements dissociate the U1 and U4 snRNPs, and association of the NineTeen Complex (NTC in yeast; Prp19-CDC5 complex in humans) of proteins leads to formation of the activated $\mathrm{B}^{\star}$ complex that is primed for catalysis. C complex is generated by the first splicing reaction and the RNA products of this step are repositioned as substrates for second-step catalysis (Bessonov et al. 2008; Konarska 2008; Wahl et al. 2009). Members of the DExD/H-box family of ATPases that utilize ATP hydrolysis to unwind RNA duplexes or to disrupt RNA-protein interactions promote these rearrangements throughout the splicing cycle (Staley and Guthrie 1998).

Prp8p is a very large and highly conserved U5 snRNP protein, and the only spliceosomal protein known to 
interact (within $2 \AA$ ) with all the reactive pre-mRNA residues, at the $5^{\prime}$ splice site, branch site, and $3^{\prime}$ splice site. It is proposed to be a protein cofactor at the spliceosomal catalytic center (Collins and Guthrie 2000; Grainger and Beggs 2005; Abelson 2008; Butcher 2009; Valadkhan and Manley 2009; Wilson and Lilley 2009). Prp8p is tightly associated with two other U5 snRNP proteins, the GTPase, Snu114p, and the DEAH-box RNA helicase, Brr2p (Achsel et al. 1998). It appears that the GTP/GDP state of Snu114p directly or indirectly (possibly via Prp8p) regulates the unwindase activity of Brr2p; therefore, proteins that interact directly with Snu114p are potentially of great importance in spliceosome activation and control.

Prp19p-associated complexes containing up to 26 proteins, have been identified by different procedures, including affinity selection of Prp19p itself (NTC) (Tsai et al. 1999; Chen et al. 2002) or by association with the NTC component Ceflp (complexed with Cef1p [CWC]) (Ohi et al. 2002). Cwc21p is found associated with a large number of RNA splicing proteins, especially the NTC, U2 snRNP, and U5 snRNP (Ohi et al. 2002; Krogan et al. 2006; Khanna et al. 2009). As an NTC or NTC-related protein, Cwc21p is in a position to function within the spliceosome $\mathrm{B}^{\star}$ and $\mathrm{C}$ complexes during the stages of spliceosome activation and catalysis. Cwc21p is a short protein of 135 residues whose primary sequence has been aligned with the $\mathrm{N}$ terminus of human SRm300 (encoded by the SRRM2 gene) (Blencowe et al. 2000; Luz Ambrosio et al. 2009) and they are thought to be orthologs, although this has not been confirmed experimentally. SRm300 was first isolated through its stringent copurification with SRm160 (Blencowe et al. 1995; Blencowe et al. 1998). SRm300 has a very long C-terminal extension ( $\sim 2600$ amino acids) containing stretches of polyserine and numerous Arg/Ser di-peptide (RS domain) sequences that interact with other proteins and pre-mRNAs involved in alternative splicing events (Hertel and Graveley 2005; Long and Caceres 2009). The potential importance of SRm300 in the catalytic center was highlighted when treatment of the purified human spliceosomal C complex with $1 \mathrm{M} \mathrm{NaCl}$ revealed SRm300 to be the only SR-related protein to remain at the catalytic core (Bessonov et al. 2008; Konarska 2008). SRm300 can be purified most strongly in the human C complex, suggesting that SRm300 may function after the first chemical reaction (Bessonov et al. 2008). Here we confirm that human SRm300 is an ortholog of yeast Cwc21p.

Through extensive proteomic and genetic experiments, we show that Prp8p contains an intramolecular fold, and that Snu114p's N-terminal GTPase domain interacts with this novel Prp8p structure. Cwc21p also binds directly to this fold in Prp8p and to the C terminus of Snu114p, a region thought to undergo a substantial conformational change during spliceosome activation. These, plus a genetic interaction with Isylp, an NTC protein that has been implicated in splicing fidelity, suggest a role for Cwc21p/
SRm300 as a regulatory factor in the catalytic center of the spliceosome.

\section{RESULTS}

\section{Prp8p contains a novel intramolecular fold that interacts with Snu114p}

Prp8p is unusually large (2413 amino acids in Saccharomyces cerevisiae; 2335 amino acids in humans), and the fulllength protein performs poorly in yeast two-hybrid (Y2H) protein interaction screens (van Nues and Beggs 2001) as well as in $\mathrm{Y} 2 \mathrm{H}$ assays (Liu et al. 2006). A genetic screen of random transposon insertions in PRP8 identified three positions where Prp8p can be split into pairs of polypeptides that function in trans in vivo, suggesting the existence of four functional regions, I-IV (Fig. 1A; Boon et al. 2006). We, therefore, carried out $\mathrm{Y} 2 \mathrm{H}$ screens using functional region I $\left(\operatorname{Prp} 8 \mathrm{p}^{1-427}\right)$ or regions I plus II $\left(\operatorname{Prp} 8 \mathrm{p}^{1-770}\right)$ as bait polypeptides.

Prp8 $\mathrm{p}^{1-427}$ as bait identified some previously known interactors, including Prp40p and Prp39p (Supplemental Table S1; Abovich and Rosbash 1997; van Nues and Beggs 2001) and also a number of overlapping clones of Prp $8 p$ itself that have 123 amino acids in common (Fig. 1B, amino acids 420-542). The Prp8p $\mathrm{p}^{420-542}$ polypeptide was then used as bait in $\mathrm{Y} 2 \mathrm{H}$ screen 2 (Supplemental Table S2), identifying 63 overlapping clones of Prp8p domain I, which encompass residues 342-423. These reciprocal results from screens 1 and 2 indicate an intramolecular interaction involving amino acids 342-542 of Prp8p, which span the transposon-partition sites between regions I and II. All of the $\mathrm{Y} 2 \mathrm{H}$ interactions presented here are of high statistical significance as they represent multiple overlapping clones and are reciprocal.

Additionally, Prp8 $\mathrm{p}^{420-542}$ selected fragments of the $\mathrm{N}$-terminal half of Snu114p in screen 2. This complements a previous $\mathrm{Y} 2 \mathrm{H}$ result, in which full-length Snu114p selected Prp8p fragments from this region (overlapping at amino acids 420-464) (Dix et al. 1998; Grainger and Beggs 2005). These residue numbers refer to the minimal regions of interaction of overlapping prey polypeptides, and larger clones produce stronger interactions. In a pairwise $\mathrm{Y} 2 \mathrm{H}$ test, the interaction between the slightly larger $\operatorname{Prp} 8^{253-543}$ and full-length Snu114p appears to be strong, based on resistance to $200 \mathrm{mM} 3$-aminotriazole (Fig. 1C, 3-AT). This is consistent with the strong interaction reported between human Prp8p and Snu114p in native complexes (Achsel et al. 1998).

\section{Cwc21p interacts directly with Prp8p and Snu114p}

In $\mathrm{Y} 2 \mathrm{H}$ screen 3 (with the same prey library), Prp8 $\mathrm{p}^{1-770}$ as bait identified some previously known interactors, including Prp40p and Lin1p/Snu40p (Supplemental Table S3). 

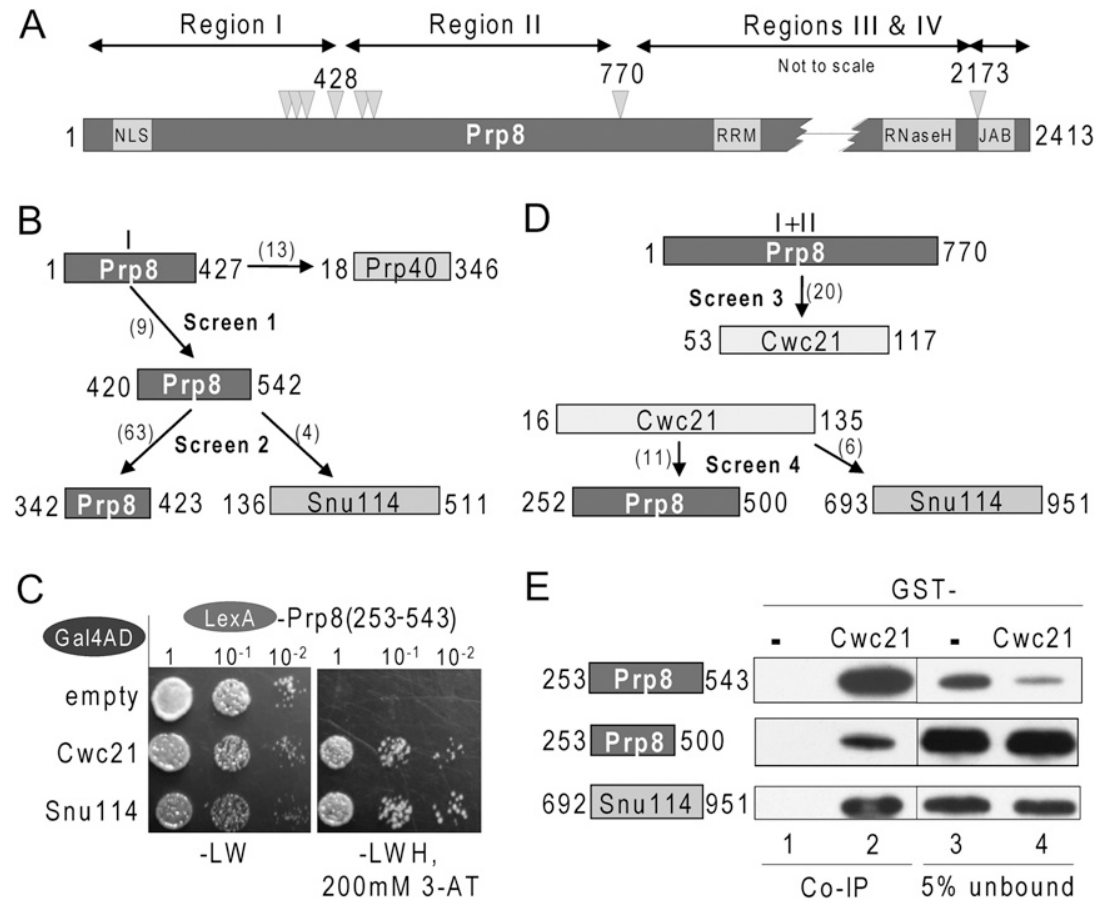

FIGURE 1. Prp8p, Snu114p, and Cwc21p interact directly with each other. (A) Schematic diagram of Prp8p showing the four regions defined by transposon insertion sites (between amino acids 394 and 443, indicated by triangles) (Boon et al. 2006). Numbers refer to amino acid residues in Prp8p. Known domains are boxed (Grainger and Beggs 2005; Abelson 2008). $(B, D)$ Schematic summary of the four $\mathrm{Y} 2 \mathrm{H}$ screens. Screen 1 used Region I of Prp8p, residues 1-427, as bait. Screen 2 used a recloned prey fragment of Prp8p, residues 420-542 as bait. Screen 3 used Regions I and II of Prp8p, residues 1-770, as bait. Screen 4 used a recloned prey fragment of Cwc21p, residues 16-135, as bait. Prey fragments shown are the minimal regions of interaction, derived from overlapping fragments. They are all classified as A, meaning that they are of high statistical significance (Fromont-Racine et al. 1997). Numbers in parenthesis represent the number of overlapping clones identified. (C) $\mathrm{Y} 2 \mathrm{H}$ interactions between Prp8p residues 253-543 and full-length Cwc21p or Snu114p. Growth in the absence of histidine $(-\mathrm{H})$ requires interaction of the proteins, and growth with $200 \mathrm{mM} 3$-AT indicates a very strong interaction. (E) Recombinant proteins were produced in E. coli. GST alone (lanes 1,3) and GST-Cwc21 $1^{16-135}$ (lanes 2,4) were combined with His $_{6}$-fusions of Prp8p or Snu114p (residues as indicated) and incubated with glutathione beads. The pull-down of Prp8p and Snu114p shows that they interact directly with Cwc21p. The decreased level of interaction with $\operatorname{Prp} 8 \mathrm{p}^{253-500}$ indicates that (part of) a binding site for Cwc21p on Prp8 $\mathrm{p}$ resides in residues 500-543.

Prp8 $\mathrm{p}^{1-770}$ also selected 20 clones of the NTC-associated Cwc21p, all of which contain a central region encompassing amino acids 53-117 (Fig. 1D).

One of the larger prey fragments, Cwc21 $\mathrm{p}^{16-135}$, was then used as bait in a fourth $\mathrm{Y} 2 \mathrm{H}$ screen, and pulled out 11 Prp8p clones, with overlap of amino acids 252-500 (Supplemental Table S4), a region that corresponds approximately with the proposed Prp8p intramolecular fold. The failure to select any of the smaller Prp8 polypeptides that were identified in screens 1 and 2, suggests that Cwc21p requires a more complex binding site for its interaction with Prp8p. This is supported by the finding that neither Prp8 $\mathrm{p}^{1-427}$ nor Prp8 $\mathrm{p}^{420-542}$ interacted with Cwc21 $\mathrm{p}^{16-135}$ in pairwise $\mathrm{Y} 2 \mathrm{H}$ tests (data not shown). Screen 4 also identified the C terminus of Snu114p (amino acids 693951) as interacting with Cwc21p (Fig. 1D). Therefore, overall, the $\mathrm{Y} 2 \mathrm{H}$ screens show a triangulation of protein-protein interactions between the intramolecular fold of Prp8p, Cwc21p, and each end of Snu114p.

Recombinant proteins fused at the $\mathrm{N}$ terminus to GST or hexa-histidine tags were produced in bacteria, including two Prp8 polypeptides, Prp8 $\mathrm{p}^{253-500}$ and Prp8 $\mathrm{p}^{253-543}$. In pull-down assays, recombinant Cwc21 $\mathrm{p}^{16-135}$ pulled down Prp8 $\mathrm{p}^{253-543}$ more efficiently ( $>5 \%$ of total) than Prp8p ${ }^{253-500}$ (Fig. 1E, $<5 \%$ of total), suggesting that amino acids 500 to 543 of Prp8p contribute to binding Cwc21p. Recombinant Cwc21p also pulled down recombinant Snu114 $\mathrm{p}^{62-951}$. Thus, Cwc21p interacts directly with Prp8p and with a C-terminal portion of Snu114p.

\section{Reciprocal Prp8p and Cwc21p binding footprints identified using BS $^{3}$ cross-linking}

$\mathrm{BS}^{3}$ is a homo-bifunctional cross-linking agent, containing two terminal aminereactive esters linked by an $11.4 \AA$ spacer that reacts specifically with primary amine groups $\left(-\mathrm{NH}_{2}\right)$ on available lysines as well as with the free aminoterminal residue of proteins. $\mathrm{BS}^{3}$ has been commonly used to identify nearest neighbor protein contacts in multiprotein complexes (Sinz 2006; Sharon and Robinson 2007). We used BS ${ }^{3}$ crosslinking to elucidate the arrangement of Prp8p's intramolecular fold and to map the protein interaction footprints between Prp8p and Cwc21p.

Purified recombinant Cwc21p and Prp8p $\mathrm{p}^{253-543}$ were incubated separately or together and then with $\mathrm{BS}^{3}$, following which a slowly migrating cross-linked Cwc21p$\mathrm{BS}^{3}-\operatorname{Prp} 8 \mathrm{p}$ species could be identified in denaturing gels. After separate in-gel digestion of the proteins with three different proteases, mass spectrometric analysis (MALDITOF) was performed. The total peptide masses were compared for (1) each individual protein with no $\mathrm{BS}^{3}$ treatment (negative control), (2) each individual protein plus $\mathrm{BS}^{3}$ (showing intramolecular cross-links), and (3) the two proteins mixed together plus $\mathrm{BS}^{3}$ (to deduce intermolecular cross-links). The resulting masses were analyzed through the online software Automated Spectrum Assignment Program (ASAP) (Lee et al. 2007) and SearchXlinks (Wefing et al. 2006). Only masses that uniquely identified 
$\mathrm{BS}^{3}$ linked peptides were analyzed further. Some lysine residues seemed to be more reactive than others but, for simplicity, each lysine was scored as either cross-linked or uncross-linked. This allowed the identification of solvent accessible lysines in Prp8 $\mathrm{p}^{253-543}$ and Cwc21p that are $\sim 11$ $\AA$ apart within their tertiary structures. The loss of reactivity of some of these lysines when Prp8p and Cwc21p are incubated together highlights the reciprocal "lysine footprints" on the two proteins.

For Prp8 $\mathrm{p}^{253-543}$ incubated alone with $\mathrm{BS}^{3}$, all lysines except K447 and K474 became cross-linked (Fig. 2A; Supplemental Table S5) and were therefore accessible to the $\mathrm{BS}^{3}$. These Prp8p intramolecular cross-links show that the two ends of $\operatorname{Prp} 8 \mathrm{p}^{253-543}$ are in close proximity, suggesting that $\operatorname{Prp} 8 \mathrm{p}^{253-543}$ forms an intramolecular fold around a solvent inaccessible core that encompasses the amino acids K447 and K474.

Upon interaction of $\operatorname{Prp} 8 \mathrm{p}^{253-543}$ with Cwc21p the lysines at the protein-protein interface are likely to be inaccessible to $\mathrm{BS}^{3}$. There are two "lysine-footprints" (amino acids 300-332 and 491-516) in $\operatorname{Prp} 8 \mathrm{p}^{253-543}$ as a result of the interaction with Cwc21p, and one Prp8p footprint in the center of Cwc21p (amino acids 53-97) (Fig. 2A). An alternative explanation for the loss of reactivity of lysines in these regions is that when the two proteins interact they undergo conformational changes that make these lysines inaccessible. However, these regions are flanked by intermolecular cross-links, indicating that they

A

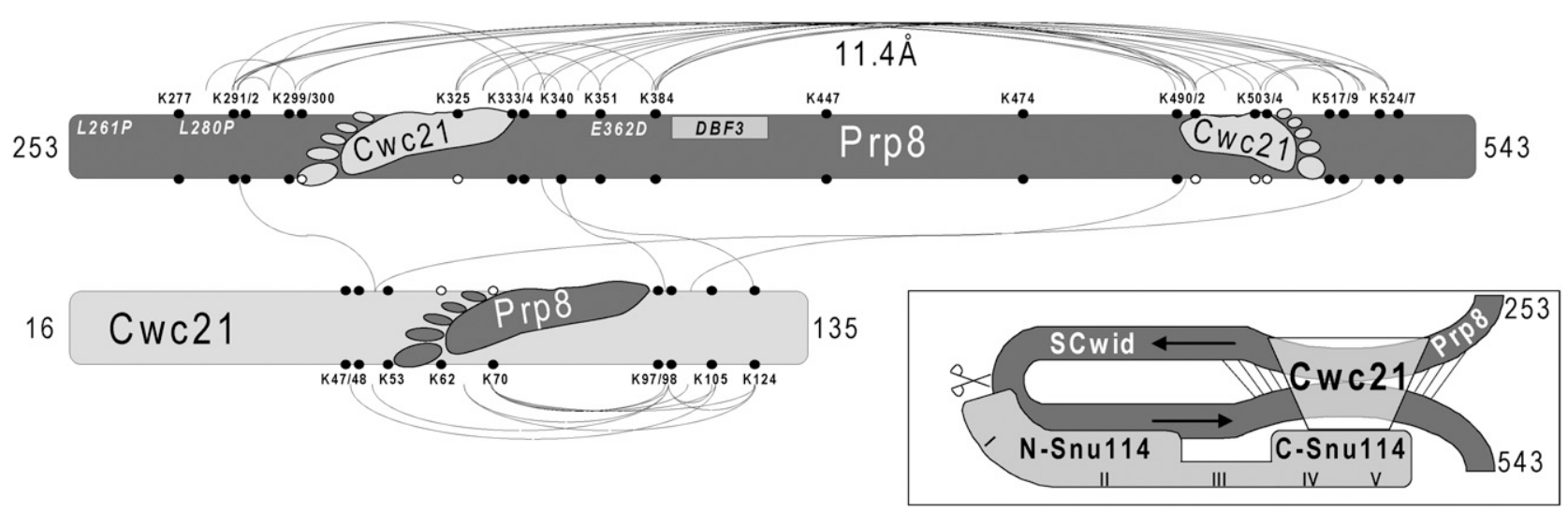

B

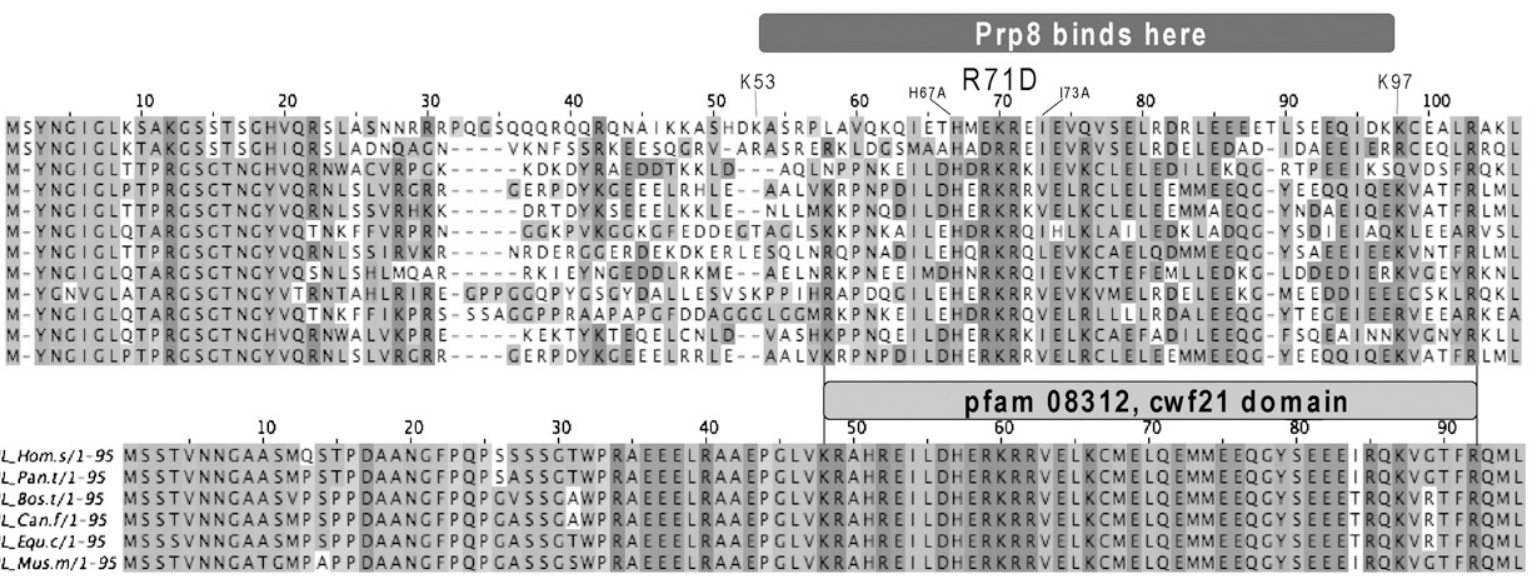

FIGURE 2. Prp8p contains an intramolecular fold that can be cross-linked to the conserved cwf 21 domain in Cwc21p. (A) Schematic diagram showing the intramolecular $\mathrm{BS}^{3}$ cross-links identified by mass spectrometry for recombinant Prp ${ }^{253-543}$ and Cwc2 $1^{16-135}$, with all lysines indicated by circles. Cross-links connecting lysines or peptides containing two lysines are shown by a line. Only uniquely assigned lysine/peptide cross-links are shown. The complete data are tabulated in Supplemental Table S5. The positions of three U4cs-1 suppressor alleles are indicated in italics (L280P is also a prp28-1 suppressor) and DBF3 indicates the position of a 34 amino acids polymorphism (Shea et al. 1994). Binding Prp8p to Cwc21p resulted in a number of previously reactive lysines (black circles) now showing no reactivity to BS ${ }^{3}$ (open circles); these were plotted to show reciprocal "lysine footprints." Inset: cartoon summarizing the interactions shown in Figures 1 and 2. The intermolecular BS ${ }^{3}$ cross-links indicate that the two interacting regions of Prp8p run antiparallel to each other in this novel structure that we refer to as SCwid (residues 253543). The location where transposon insertions are tolerated (Boon et al. 2006) is indicated by scissors. The approximate positions of domains I-V in Snu114p are shown. (B) Alignment of the Cwc21p/SRm300/SRRM2 family showing the highly conserved regions as calculated by the Muscle program (Edgar 2004) and highlighted using Jalview (Waterhouse et al. 2009) (numbers above refer to budding yeast Cwc21p). The Prp8p "lysine footprint" and pfam's cwf21 domain of unknown function are indicated; their near complete overlap suggests that this highly conserved domain functions to bind directly to Prp8p. (C) An additional conserved protein known as SRRM2-like (SRRM2L) also contains the cwf21 domain near its $\mathrm{N}$ terminus; however, the $\mathrm{N}$ terminus itself is different from Cwc $21 \mathrm{p} / \mathrm{SRm} 300$ and its function is unknown. 
are indeed sites of interaction of the two proteins. These results are in agreement with the $\mathrm{Y} 2 \mathrm{H}$ data and with the recombinant protein binding studies. The two separate footprints on Prp8p can explain why Cwc21p interacts with the large Prp8 $\mathrm{p}^{253-500}$ fragment, but not with smaller fragments, as the interaction requires two binding sites that are juxtaposed via an intramolecular fold. The extent of the footprints on Prp8p can explain why Cwc21p bound more strongly to $\operatorname{Prp} 8 \mathrm{p}^{253-543}$ than to $\operatorname{Prp} 8 \mathrm{p}^{253-500}$, which lacks part of one binding site.

The Prp8p "lysine footprint" on Cwc21p was determined as being between $\mathrm{K} 53$ and K97. The orientation of the intermolecular cross-links observed between Prp8p and Cwc21p indicates that this region of Prp8p is folded in an anti-parallel arrangement (Fig. 2A, inset) that we will refer to as the Snu114/Cwc21 interacting domain (SCwid).

\section{Cwc21p, SRm300, SRRM2L, and the cwf21 domain}

An alignment of the Cwc21p family sequences (Fig. 2B) shows a conserved region of around 100 amino acids at the $\mathrm{N}$ terminus of each protein, and highlights three features: (1) a conserved $\mathrm{N}$-terminal motif of about 24 amino acids, (2) a variable linker region, and (3) a conserved cwf21 domain (pfam 08312, IPR013170) (Finn et al. 2008), named after cwf21, the Schizosaccharomyces pombe ortho$\log$. The Prp8p binding site on Cwc21p corresponds exactly to the cwf21 domain, which can explain the evolutionary conservation of this region. Proteins of the Cwc21/SRm 300 family are usually larger in higher eukaryotes due to extended C-termini that can be 2000 or more amino acids long. These extensions are made up of poly-serine stretches and RS di-peptide repeats, the latter being known to direct protein-protein or protein-RNA interactions (Hertel and Graveley 2005). However, cDNA clones indicate production of a smaller 194-196 residue SRm300/SRRM2 protein in many tissues in higher eukaryotes (Strausberg et al. 2002). A BLAST search with the cwf 21 domain identified another protein, known as SRRM2-Like (SRRM2L) protein (Fig. 2C) that is usually $\sim 600-700$ amino acids long. SRRM2L is only present in vertebrates and conceivably may have a role in development. Curiously, the U2associated SR140 protein has a partial cwf21 domain and a partial structure is known (PDB 2e62).

\section{CWC21 interacts genetically with ISY1}

CWC21 is not required for cell viability under normal growth conditions. A sensitive and quantitative genetic interaction mapping (GIM) screen was carried out to determine if deletion of CWC21 has a synthetic genetic interaction with any of the other $\sim 4400$ nonessential genes in yeast (Decourty et al. 2008). The GIM screen with cwc21 $1 \Delta$ identified a cluster of functionally related genes that are highlighted in Figure 3A. The five deletions that showed the greatest growth defect when combined with $c w c 21 \Delta$ included four genes that encode RNA splicing factors: Isylp, Ntc20p, Syf2p, and Snu66p. Isylp, Ntc20p, and Syf2p are NTC components and are part of a stable NTC90 subcomplex, named after the essential component Syflp (also known as Ntc90p) (Chen et al. 2002; Dahan and Kupiec 2002). Snu66p is a component of U4/U6•U5 trisnRNPs and deletion of SNU66 enhances the growth defects of several snu114 alleles (Brenner and Guthrie 2005). This supports a role for Cwc21p in pre-mRNA splicing and with the NTC, a role that is supported by other genetic studies (Hausmann et al. 2008; Wilmes et al. 2008; Khanna et al. 2009).

A more unexpected synthetic interaction that was observed with deletion of ERD1 may be explained by an indirect genetic link. ERD2 is one of a small number of intron-containing transcripts that are poorly spliced $(<50 \%)$ in a $c w c 21 \Delta$ strain under normal growth conditions (Burckin et al. 2005). ERD2 is an essential, introncontaining gene that interacts with ERD1 (Miller et al. 2005), with both proteins functioning to retain KDEL proteins in the endoplasmic reticulum (ER). Thus, $c w c 21 \Delta$ causes reduced levels of Erd2p and the additional loss of Erdlp may explain the growth defect. In support of this, another genome-wide screen showed that Cwc21p has a significant role in ER homeostasis; deletion of CWC21 causes unregulated ER to Golgi transport (Copic et al. 2009).

Testing the double deletions of $c w c 21 \Delta$ with erd1s, $n t c 20 \Delta$, or syf $2 \Delta$ did not show a significant growth defect on a plate assay (less sensitive than the liquid assay used in the GIM screen) (data not shown); however, $c w c 21 \Delta / i s y 1 \Delta$ grew slowly at $30^{\circ} \mathrm{C}$ and failed to grow at $37^{\circ} \mathrm{C}$ (Fig. $3 \mathrm{~B}$ ). As the $c w c 21 \Delta / i s y 1 \Delta$ temperature-sensitive phenotype is fast acting, the effect of temperature on splicing was investigated using an oligo-based microarray that detects all of the intron-containing and spliced mRNA transcripts in S. cerevisiae. A genome-wide accumulation of introns, coupled with a corresponding decrease in the mature mRNA levels, was observed with RNA from the mutant strain grown at $30^{\circ} \mathrm{C}$, and the splicing defect increased after $30 \mathrm{~min}$ at $37^{\circ} \mathrm{C}$ (summarized in Fig. 3C; Supplemental Table S6). Among the top 40 most affected transcripts whose functions are known, 37 encode ribosomal proteins, translation factors (EFB1, TEF4) or a snoRNA involved in ribosome synthesis $(S N R 17 A / B)$. It was previously reported that, compared with other transcripts, the splicing of ribosomal protein transcripts shows a distinct response to conditions of stress, such as amino acid starvation and exposure to ethanol (Pleiss et al. 2007). It is therefore conceivable that the preferential accumulation of unspliced ribosomal protein transcripts observed here is a conse-

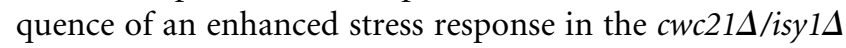
strain. An examination of the transcripts that showed strong splicing defects in the $c w c 21 \Delta / i s y 1 \Delta$ strain showed that the $5^{\prime}$ splice site, branch site, and $3^{\prime}$ splice site 

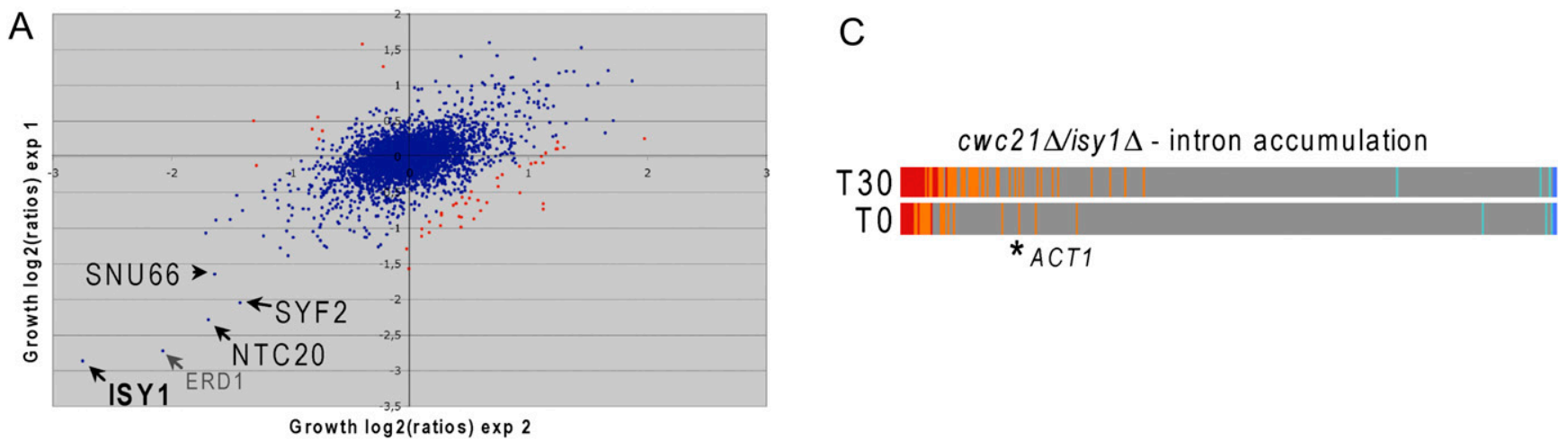

B

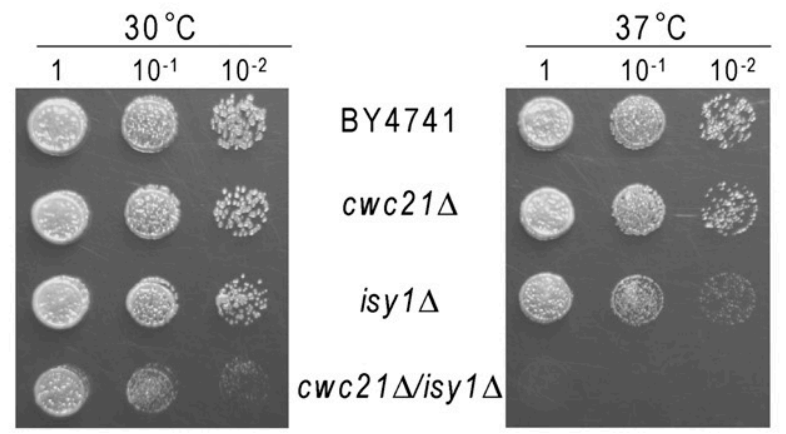

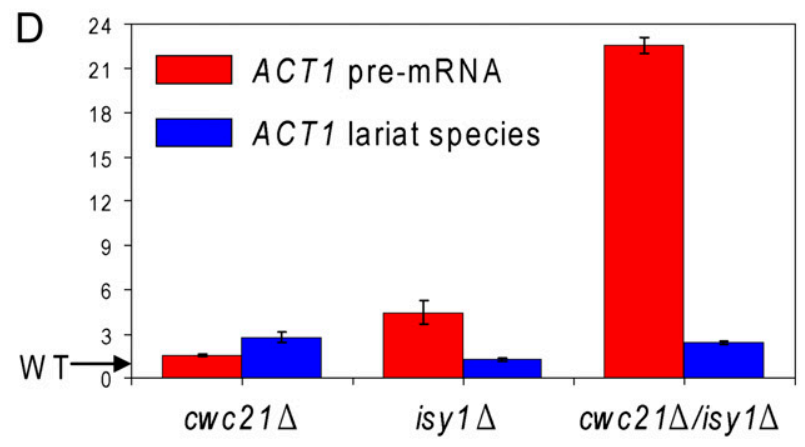

FIGURE 3. $c w c 21 \Delta$ has a synthetic genetic and functional interaction with isy1s. (A) A genetic screen with $c w c 21 \Delta$. The relative growth rates of double-deletion strains obtained in two independent GIM screens are represented as a scatter plot to assess the reproducibility of the assay and to identify strong interactions (Decourty et al. 2008). The genes whose deletion was synthetic lethal or caused synthetic growth inhibition when combined with $c w c 21 \Delta$ are found in the lower-left quadrant. (B) The slow-growth phenotype of $c w c 21 \Delta /$ isyld identified in the GIM screen was confirmed on YPDA plates at $30^{\circ} \mathrm{C}$ and the heat sensitivity is shown at $37^{\circ} \mathrm{C}$. (C) Microarray analysis of intron-containing transcripts from the $c w c 21 \Delta /$ isy $1 \Delta$ strain compared with wild-type (BY4741) grown at $30^{\circ} \mathrm{C}(\mathrm{T} 0)$ and after shifting to $37^{\circ} \mathrm{C}$ for $30 \mathrm{~min}$ (T30), identified a broad defect in pre-mRNA splicing. Red bars indicate introns whose abundance is twofold greater, orange $=1.6$-fold greater, light blue $=1.6$-fold lower, dark blue $=$ twofold lower in the mutant than in wild type. The full data set is presented in Supplemental Table S6. ACT1 $\left({ }^{*}\right)$ was chosen for quantitative PCR analysis. (D) Quantitative real-time PCR to measure pre-mRNA or lariat-containing species in ACT1 RNA from single or double mutant cells grown at $37^{\circ} \mathrm{C}$ for $30 \mathrm{~min}$. Values are relative to wild-type (WT). Bars indicate the standard error from at least two biological replicates. The $c w c 21 \Delta$ /isy $1 \Delta$ double-mutant strain showed a $>20$-fold increase in pre-mRNA compared with wild type, indicating a strong step 1 splicing defect. The single-deletion strains showed a lower level of pre-mRNA or lariat accumulation that did not affect growth.

sequences do not differ significantly from the consensus sequences. ACT1 transcripts were then analyzed by quantitative real-time PCR to detect unspliced pre-mRNA or the lariat form of the intron. A $>20$-fold accumulation of unspliced ACT1 pre-mRNA was observed in the double mutant compared with wild type at the restrictive temperature, with very little or no lariat species, indicating that the $c w c 21 \Delta / i s y 1 \Delta$ strain has a block at or prior to the first catalytic step of splicing (Fig. 3D). In comparison, RNA from the isy $1 \Delta$ and cwc21s single mutants showed only a mild or no significant splicing defect, respectively. The much greater accumulation of pre-mRNA in the double mutant compared with either single mutant can explain their synthetic genetic interaction, and suggests that Cwc21p and Isylp may have related functions at or prior to the first step of splicing, making them partially redundant. However, whereas deletion of ISY1 has been shown to rescue the coldsensitive phenotype of prp16-302, this is not the case with $c w c 21 \Delta$ (data not shown), indicating that the two proteins do not have an identical function.

\section{Cwc21p is orthologous to human SRm300}

The temperature sensitivity caused by deletion of both CWC21 and ISY1 provides a test system for the identification of functionally important $c w c 21$ mutations as well as for complementation by CWC21 orthologs. Thus, the N-terminal 159 amino acids of human SRm300 was shown to partially suppress the temperature-sensitive growth defect of $c w c 21 \Delta /$ isy $1 \Delta$ cells at $36^{\circ} \mathrm{C}$ (Fig. $\left.4 \mathrm{~A}\right)$. In this experiment the Cwc21p and SRm $300^{1-159}$ proteins were present at the same level, expressed from the $P_{\text {MET25 }}$ promoter (data not shown); therefore, the slower growth observed with SRm $300^{1-159}$ probably reflects the cumulative evolutionary divergence between the two proteins that likely affects their interactions. Thus, human SRm300 functions as an ortholog of yeast Cwc21p.

Comparing the properties of the purified recombinant Cwc2 1 and SRm300 ${ }^{1-159}$ proteins in vitro, SRm300 ${ }^{1-159}$ was shown to pull down recombinant yeast Prp8p $\mathrm{p}^{253-543}$, although somewhat less efficiently than Cwc21p (Fig. 4B). 
A
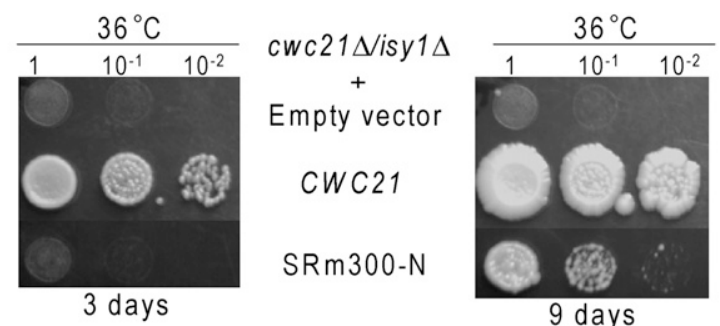

B

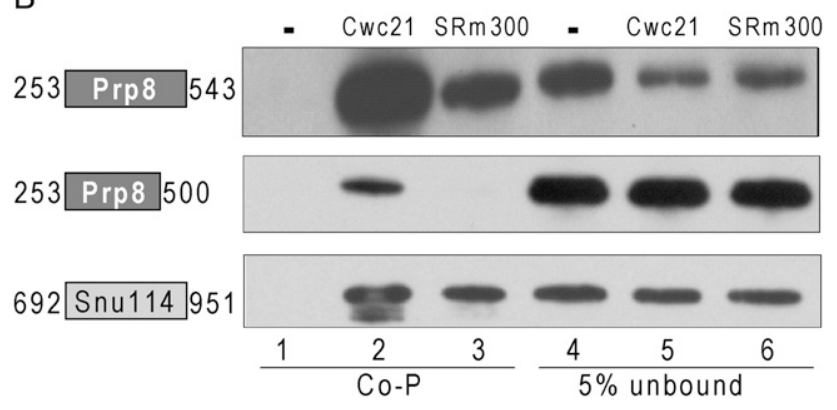

FIGURE 4. Human SRm300/SRRM2 can functionally substitute for Cwc21p in yeast. (A) CWC21 and SRRM2-N (encodes the N-terminal 159 residues of SRm300, "SRm300-N") were cloned on plasmids under control of $P_{M E T 25}$ which, in the presence of $5 \mathrm{mM}$ methionine, produces equivalent levels of each protein, and the same as from the natural CWC21 promoter (data not shown). Rescue of $c w c 21 \Delta / i s y 1 \Delta$ 's temperature-sensitive phenotype indicates that SRm300 is a human ortholog of yeast Cwc21. Serial dilutions of spotted cells were photographed after the indicated time at $36^{\circ} \mathrm{C}$. (B) Recombinant proteins: GST alone (-, lanes 1,4), GST-Cwc21, residues 16-135 (lanes 2,5) and GST-SRm300-N, residues 1-159 (lanes 3,6) were combined with $\mathrm{His}_{6}$-fusions of Prp8 and Snu114 (residues as indicated). The pull downs (Co-P) indicate that human SRm300 interacts directly with yeast Prp8p and Snu114p. The lack of interaction with $\operatorname{Prp} 8^{253-500}$ indicates that the binding site for SRm300 on Prp8p extends into residues 500-543.

SRm300 ${ }^{1-159}$ did not detectably pull down the shorter Prp8 $\mathrm{p}^{253-500}$, confirming the importance of Prp8p amino acids 500-543 for binding to Cwc21 proteins. In contrast, yeast Snu114 $\mathrm{p}^{692-951}$ interacted equally well with human SRm $300^{1-159}$ and yeast Cwc21p. The slower growth of isy1s yeast cells that have Cwc21p replaced by SRm300 could therefore be a consequence of the weaker interaction of SRm300 with yeast Prp8p.

\section{The cwf21 domain in Cwc21p is important in vivo}

The $c w c 21 \Delta / i s y 1 \Delta$ complementation assay was then used to test the effect of mutating conserved residues in the Prp8p binding site of Cwc21p, encoded on a plasmid. Compared with wild-type Cwc21p, the mutant variants H67A, R71D, and $173 \mathrm{~A}$ resulted in slower growth at $37^{\circ} \mathrm{C}$, with $\mathrm{R} 71 \mathrm{D}$ having the most severe defect (Fig. 5A). As the temperature-sensitive growth of the $c w c 21 \Delta / i s y 1 \Delta$ strain could be mostly rescued by overproducing the mutant proteins (data not shown), the mutations did not completely inactivate Cwc21p. The severity of the growth defects observed with the mutant proteins correlated with the effect of the mutations on association of Cwc21p with Prp8p and Snu114p in yeast extract, with R71D having the most severe effect (Fig. 5B, cf. lanes 2,3 and 4). Thus, mutation of three conserved residues in the cwf 21 domain confirmed the importance of this motif for binding of Cwc21p to Prp8p in vivo and suggests that this interaction is important for normal cell growth in the absence of Isylp.

\section{DISCUSSION}

We demonstrate here that Cwc21p, an NTC-associated protein is orthologous to the human splicing factor SRm300 and that both can bind directly to two key splicing factors; Prp8p, a likely cofactor in splicing catalysis, and Snu114p, the only GTPase in the spliceosome. CWC21 interacts genetically with $I S Y 1$, a proposed fidelity factor that promotes a spliceosomal conformation favorable for first-step chemistry (Villa and Guthrie 2005; see below). We propose that Cwc21p functions at a similar stage in the splicing cycle, at or prior to the first chemical step of splicing, possibly through its interaction with Prp8p and Snu114p. Consistent with this, Luz Abrosio et al. (2009) showed that RNAi knockdown of Trypanosome U5-Cwc21 exhibited an effect on splicing prior to the first step, and Khanna et al. (2009) found yeast Cwc21p to be specifically associated with U2, U5, and U6 snRNAs, which is compatible with a role in spliceosomes after dissociation of $\mathrm{U} 1$ and $\mathrm{U} 4$.

\section{The SCwid domain in Prp8p}

We show that Prp8p contains a novel intramolecular fold that we have termed the Snu114/Cwc21 interacting domain or SCwid, to which Cwc21p/SRm300 binds directly, via the conserved cwf21 domain. Cwc21p also binds directly to the C-terminus of Snu114p, a region thought to undergo a conformational change when Snu114p binds GTP. The region of Snu114p that contains the GTP binding domain (spanning residues 134-510) interacts very strongly with Prp8p's SCwid. It has been speculated that Prp8p could be a potential GTPase-activating protein (GAP) for Snu114 (Small et al. 2006, and references therein), and the interaction of Prp8p's SCwid with Snu114p's GTP binding domain suggests how this might occur. We propose that this could be a major connection point that gives the Prp8p/Snu114p hetero-dimer its stability (Achsel et al. 1998). The in vivo $\mathrm{Y} 2 \mathrm{H}$ interaction (in the presence of $>200 \mathrm{mM} \mathrm{3-AT)}$ is very strong, as expected for two proteins that can only be separated using 0.4 M Sodium thiocyanate (Achsel et al. 1998).

We previously showed that transposon insertions can be tolerated in the region between amino acids 394 and 443 in Prp8p, and when expressed independently, the two fragments of protein either side of the insertion sites can 
A

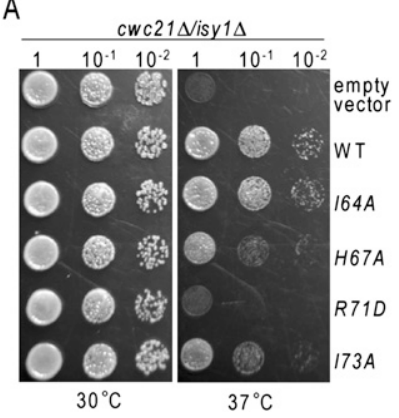

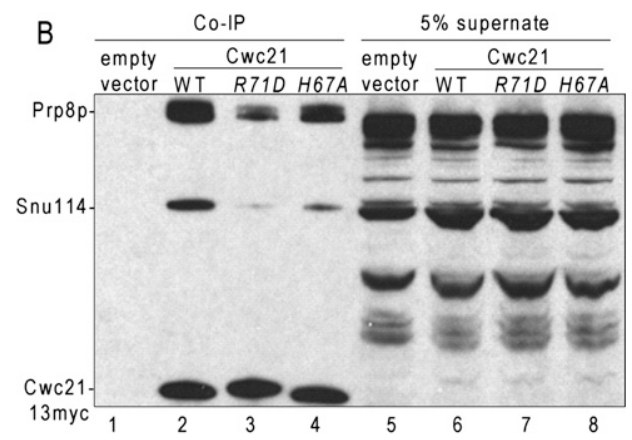

FIGURE 5. The conserved cwf21 domain in Cwc21p is important for Prp8p binding and for growth. (A) The temperature-sensitive $c w c 21 \Delta / i s y 1 \Delta$ strain was used to confirm that the cwf 21 domain is responsible for binding Prp8p and Snu114p. The wild-type and mutant CWC21 genes were cloned on plasmids under control of $P_{M E T 25}$ (see Fig. 4). Mutation of the conserved residues (indicated on the right) in the cwf 21 domain caused restrictive growth at $37^{\circ} \mathrm{C} .(B)$ Co-immunoprecipitation of Cwc21-13myc from extracts from yeast cells expressing cwf 21 domain mutants. Lanes 1 to 4 show that two mutations within Cwc21p's cwf21 domain bind less Prp8p and Snu114p in a manner correlating with the temperature-sensitive phenotypes. This confirms that the cwf21 domain is responsible for binding of Cwc21p to Prp8p and Snu114p in vivo. These residues are also highlighted in Fig. 2B. step 1. These mutations do not affect the $\mathrm{Y} 2 \mathrm{H}$ interactions described here, and may affect other interactions. As Cwc21p has been isolated along with Prp19p/Cef1p and the NTC/CWC complexes (Ohi et al. 2002), the SCwid is a potential docking site for the NTC/ CWC or NTC-related proteins (Fig. 6). The NTC associates with spliceosomes after displacement of U1 and U4 snRNPs (Chan et al. 2003). It is conceivable that the SCwid and Snu114p's $\mathrm{C}$ terminus are recognized by Cwc $21 \mathrm{p}$ only after release of U1 snRNP from Prp8p and upon the exchange of GDP for GTP in Snu114p, hence Prp8's SCwid and Cwc21p have the potential to play a major role in spliceosome activation. function in trans (Boon et al. 2006). This can now be explained; the two separate polypeptides of Prp8p can be stably held together by the SCwid structure, in which the two regions interact in an antiparallel arrangement (see Fig. 2A, inset).

The existence of the SCwid structure in Prp8p may also explain how two groups of U1 snRNP proteins appear to bind to distant regions of Prp8p (Grainger and Beggs 2005, and references therein). Prp40p and Prp39p interact N-terminally, whereas Exo84p and Snp1p interact near the middle of Prp8p, and the SCwid fold could bring these sites into proximity (Fig. 6). Ten U4-cs1 mutations lie in the RRM region, and three $U 4$-cs 1 alleles plus one prp28-1 suppressor allele lie in the SCwid (Kuhn and Brow 2000; Kuhn et al. 2002; Grainger and Beggs 2005), all of which are involved in exchanging U1 and U6 at the 5'SS prior to

\section{Cwc21p in the regulation of splicing}

Cwc21p is not essential for cell growth, and depletion of SRm300 was shown to be nonessential (under limited conditions tested) (Blencowe et al. 2000), which is compatible with function or activation of these proteins only under certain conditions. Interestingly, the Caenorhabditis elegans ortholog is essential; rsr-2 (related SR protein -2) has been shown by RNA interference to cause severe abnormalities such as sterility, embryonic lethality, larval arrest (Longman et al. 2001), multivulva and extra intestinal nuclei (Ceron et al. 2007), suggesting a possible role in development. CWC21 is one of only 125 yeast genes that are up-regulated in response to $200 \mathrm{mM} \mathrm{Ca}^{2+}$, with the level of CWC21 expression increasing 3.5-fold (Yoshimoto et al. 2002). Analysis of the promoter region upstream of CWC21 reveals a binding site for Crzlp, a factor activated

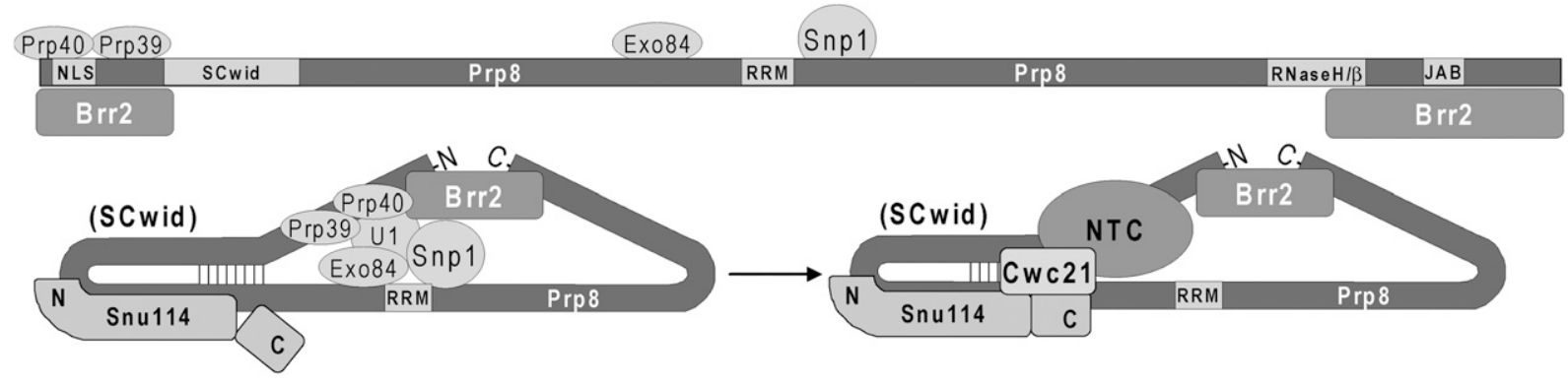

FIGURE 6. Cartoon illustrating protein interactions identified in this work and how they relate to other known protein interactions of Prp8p. Prp8p residues 253-543 form an intramolecular fold that is central to a triangulation of direct interactions with Snu114p and Cwc21p (the "SCwid hub"). The SCwid can also explain how the U1 snRNP proteins Prp39p, Prp40p, Exo84p, and Snp1p can interact with apparently distant regions of Prp8p while part of a stable U1 snRNP. Brr2p binds to the N- and C-termini of Prp8p, and thus is adjacent to Prp8p's SCwid and Snu114p. As Prp8p, Snu114p, and Brr2 are implicated in unwinding U4/U6 snRNA heterodimer at about the same time that Prp28p unwinds U1 snRNA from the 5'SS, Prp8p's SCwid is an ideal target for regulation. Significantly, U4cs-1 and prp28-1 suppressor mutations are located in the SCwid. 
by specific environmental stress conditions such as exposure to osmotic shock, mating pheromones, and elevated temperatures (Yoshimoto et al. 2002; Monteiro et al. 2008). Expression of SRm300/SRRM2 also increases by 2.6-fold upon induction by calcium (Zagranichnaya et al. 2005), suggesting a conserved mode of regulation. The link between Cwc21p, ERD2 pre-mRNA splicing, and ER homeostasis (Copic et al. 2009) discussed above may be relevant to this.

We found that the cwc21s/isy1s double-mutant strain displayed heat-sensitive growth and a first step splicing defect that was enhanced at elevated temperature. This resulted in preferential accumulation of transcripts that encode ribosomal proteins or other factors involved in translation. Similarly, in the accompanying paper Khanna et al. (2009) through a tiling array analysis of $c w c 21 \Delta$, isy $1 \Delta$ single and double mutants grown at the permissive temperature revealed significant enrichment of introns for genes whose functional categories include translation, post-translational modification and reproduction. Therefore, Cwc21p and/or Isylp may regulate the splicing of these categories of transcripts in response to stresses such as high temperature or changes in other cellular conditions. Alternatively, the preferential accumulation of unspliced transcripts encoding ribosomal proteins and translation factors may reflect the fact that they are very abundant and therefore more likely to be affected by a splicing defect. Conceivably, a conformational change or post-translational modification in the SCwid or Cwc21p could immediately inhibit spliceosome activation by the NTC. This suggests a potential mechanism whereby Cwc $21 \mathrm{p}$ might affect the splicing of some or all transcripts in response to environmental or metabolic changes (Pleiss et al. 2007).

\section{SRm300 is a human ortholog of Cwc21p}

The sequence similarities between Cwc21p and the $\mathrm{N}$ terminus of the human SRm300 have been noted previously (Blencowe et al. 2000; Luz Ambrosio et al. 2009). We confirm here that the N-terminal 159 amino acids of human SRm300 can functionally substitute for yeast Cwc21p in vivo and that both bind directly to the yeast Prp8p SCwid via a conserved region called the cwf 21 domain. Mutating the cwf 21 domain confirmed its function in vivo and that arginine 71 is critical for the interaction with Prp8p and Snu114p. Careful alignments show that higher eukaryotes have another potential Prp8p binding protein called SRRM2-like protein. Its function is unknown, but its cwf 21 domain allows us to speculate that it might be a vertebrate-specific splicing factor. Considering that SRm300 is the only SR-related protein found at the center of the human spliceosome, and most strongly in the C complex (after step 1) (Bessonov et al. 2008; Konarska 2008) we propose that its presence at the catalytic center may be mediated by its interactions with hPrp8 and
hSnu114. Conceivably, the long RS-domain of SRm300 could transmit responses from different environmental stimuli directly to the catalytic center.

\section{Cwc21p genetics, its role in splicing, and its relationship with Isy1p}

The GIM screen showed that Cwc21p interacts genetically with a cluster of known NTC proteins, including Isylp, Syf2p, and Ntc20p, confirming Cwc21p's close role with the NTC, as well as with the tri-snRNP protein Snu66p. As in the accompanying paper (Khanna et al. 2009), we also found that isy1s produced the greatest synthetic defect with $c w c 21 \Delta$. The most useful genetic tool we found was that the $c w c 21 \Delta / i s y 1 \Delta$ double mutant produced a temperature-sensitive phenotype, and was shown by microarray analysis and quantitative PCR to inhibit pre-mRNA splicing at or prior to the first step of pre-mRNA splicing. Indeed, isy $1 \Delta$ itself decreases the efficiency of the first step of splicing (Fig. 3D; Villa and Guthrie 2005; Khanna et al. 2009), and it was proposed that Isylp promotes a spliceosomal conformation favorable for first-step chemistry (Villa and Guthrie 2005). The synthetic genetic interaction between ISY1 and CWC21 and the enhanced firststep splicing defect in the double mutant suggest that they may function in the same complex, or that their functions are mutually redundant. Although Cwc21p and Isylp are functionally related, their functions seem not to be identical, as evidenced by suppression of prp16-302 by isy1 $\Delta$ but not by $c w c 21 \Delta$.

Prp16p is a DEAH-box RNA-stimulated ATPase that appears to interact only transiently with spliceosomes to promote a structural transition required for second-step chemistry (Schwer and Guthrie 1991; Schwer and Guthrie 1992). The cold-sensitive prp16-302 allele causes the protein to stall in spliceosomes at low temperature, and premRNAs with aberrant branch sites are spliced at increased frequency. The cold-sensitive growth caused by this prp16 allele is suppressed by mutations that weaken a U2/U6 snRNA structure called helix I in the catalytic center, and it was proposed that Prp16p destabilizes helix I to allow a rearrangement of the catalytic center for the second step of splicing (Mefford and Staley 2009). The prp16-302 defect is also suppressed by loss of the NTC protein Isylp that, although not essential, is required for optimal splicing of certain poorly spliced introns (Dix et al. 1999). Deletion of ISY1 appears to release the stalled prp16-302 spliceosome and restore fidelity of branch site usage (Villa and Guthrie 2005). It was proposed that Isylp functions together with U6 snRNA to promote the spliceosomal conformation for first-step chemistry (Villa and Guthrie 2005). According to a model that proposes an equilibrium between conformational states of the spliceosome (Konarska et al. 2006; Smith et al. 2008), deletion of ISY1 may promote second step chemistry, explaining the reduced fidelity of $3^{\prime}$ splice 
site selection that was observed with isy $1 \Delta$ in the presence of wild-type Prp16p (Villa and Guthrie 2005).

We propose that Isylp and Cwc21p function in two distinct but related events in the catalytic center of the spliceosome. The role of Cwc21p is mediated by its direct interaction with Prp8p and Snu114p and, possibly in response to changing environmental or metabolic conditions, Cwc21p helps to stabilize the catalytic center or the position of the RNA substrate. As discussed, Cwc21p likely functions at or immediately prior to the first chemical step of splicing, however, considering the apparent equilibrium between the various spliceosomal conformations and the report that SRm300 is strongly associated with spliceosomal C complex that is formed after the first chemical reaction, we do not exclude an effect on later events. Our future studies will therefore investigate the role of Cwc21p in the regulation of splicing and in splicing fidelity under various growth conditions.

\section{MATERIALS AND METHODS}

\section{Yeast strains, plasmids, and oligonucleotides}

Yeast strains and plasmids are listed in Tables 1 and 2, respectively. Yeast manipulations were performed using standard laboratory procedures. Deletion and C-terminal tagging of CWC21 on the yeast genome was by one step PCR from a variety of templates (Longtine et al. 1998) and correct integration was confirmed by yeast colony PCR. PCR was used to amplify CWC21-13myc from YRG-C21-13myc genomic DNA and it was cloned in pRS423- $\mathrm{P}_{\mathrm{MET} 25}$ using EcoRI/XhoI to produce pRS423-P $\mathrm{P}_{\text {MET25 }}-\mathrm{Cwc} 21-13$ myc plasmid. The plasmid GSTSRm300 (Blencowe et al. 2000) was used as a template for cloning into pRS423- $\mathrm{P}_{\mathrm{MET} 25}$ and the gateway GST vector pDEST15. All recombinant plasmids were checked by sequencing. Oligonucleotide sequences used in this work are available on request.

\section{Yeast two-hybrid}

$\mathrm{Y} 2 \mathrm{H}$ screens were performed by Hybrigenics S.A. using a mating strategy (Fromont-Racine et al. 2002). The Hybrigenics' S. cerevisiae prey library was introduced in Y187 cells and mated with $\mathrm{L} 40 \Delta \mathrm{G}$ cells that produced LexA-bait fusion proteins (www.hybrigenics.com). Tests with pairwise protein combinations involved $\mathrm{L} 40 \Delta \mathrm{G}$ cells only.

\section{Cloning, mutagenesis, and recombinant proteins}

Recombinant plasmids for protein expression were produced using the Gateway system (Invitrogen). Mutagenesis of the Cwc21-13myc plasmids was achieved using a home-made version of the "QuickChange protocol" of Stratagene. For recombinant protein production, Escherichia coli BL21(DE3)pLysS cells (Invitrogen) grown overnight at $37^{\circ} \mathrm{C}$ in $50 \mathrm{~mL} \mathrm{LB}$ containing $100 \mu \mathrm{g} / \mathrm{mL}$ ampicillin and $34 \mu \mathrm{g} / \mathrm{mL}$ chloramphenicol were inoculated into $1 \mathrm{~L}$ of LB in a 5-L flask at $37^{\circ} \mathrm{C}$. At OD $600_{\mathrm{nm}}$ of 0.6 (about $1 \mathrm{~h}$ later), $0.238 \mathrm{~g}$ of IPTG powder $(1 \mathrm{mM})$ was added and the culture shifted to $30^{\circ} \mathrm{C}$ for 3-4 h. Cells were pelleted, resuspended in $30 \mathrm{~mL}$ of lysis buffer (20 mM HEPES at pH 7.5, $200 \mathrm{mM} \mathrm{NaCl}, 100 \mu \mathrm{M}$ EDTA, $10 \mathrm{mM}$ $\beta$-mercaptoethanol, 1 pellet of Roche protease inhibitors), and stored at $-80^{\circ} \mathrm{C}$. Lysis involved three cycles of freeze-thaw and all subsequent procedures were carried out at $4^{\circ} \mathrm{C}$ : addition of DNase I to $5 \mu \mathrm{g} / \mathrm{mL}$ and rotation for $5 \mathrm{~min}$ followed by the addition of $1 \%(\mathrm{v} / \mathrm{v})$ Triton X-100 and rotation for $15 \mathrm{~min}$, the lysate was then spun at 17,000 rpm for $45 \mathrm{~min}$, clear supernate was removed, and proteins were affinity-purified on either GST-Sepharose or Nickel-NTA columns and dialyzed against $20 \mathrm{mM}$ HEPES at $\mathrm{pH}$ 7.9, $100 \mathrm{mM} \mathrm{NaCl}, 100 \mu \mathrm{M}$ EDTA, 1 mM DTT, 20\% glycerol. Protein yield was estimated by Bradford assay and stored at $-20^{\circ} \mathrm{C}$.

\section{Recombinant protein immunoprecipitations}

All immunoprecipitations were carried out at $4^{\circ} \mathrm{C}$. Preswollen glutathione beads were washed three times in NTN buffer $(50 \mathrm{mM}$ Tris at $\mathrm{pH} 7.5,150 \mathrm{mM} \mathrm{NaCl}, 0.1 \%$ [v/v] Nonidet P40) and once in $\mathrm{X}_{1} \mathrm{IP}_{150}(6 \mathrm{mM}$ HEPES at $\mathrm{pH} 7.9,150 \mathrm{mM} \mathrm{NaCl}, 5 \mathrm{mM}$ $\mathrm{MgCl}_{2}$ ), and resuspended in $100 \mu \mathrm{L}$ of X1 $\mathrm{IP}_{150}$. The beads ( $30 \mu \mathrm{L}$ per sample) were added to a premixed combination of proteins in a final volume of $300 \mu \mathrm{L}$, and rotated end over end for $1 \mathrm{~h}$ at $4^{\circ} \mathrm{C}$. Beads were pelleted and washed twice in NTN then twice more in NT (no NP-40) before resuspending in protein loading buffer. Western blotting and washes were performed using PBST-milk [PBS, $0.1 \%(\mathrm{v} / \mathrm{v})$ Tween 20, 5\% (w/v) nonfat dried milk] (Marvel). Incubation with primary antibodies: $\alpha$-Prp8 (8.6) (Grainger and Beggs 2005) at 1/4000; $\alpha$-Snu114 (Patrizia Fabrizio, Max Planck Institute for Biophysical Chemistry) at 1/50,000; and $\alpha$-myc-HRP (Roche) (at 1/50,000), was overnight in PBST-milk at $4^{\circ} \mathrm{C}$, and with secondary antibodies, $\alpha$-Rabbit-HRP $(1 / 20,000)$ was in PBST-milk at room temperature.

TABLE 1. Yeast strains used in this work

\begin{tabular}{|c|c|c|}
\hline Strain & Genotype & Source/reference \\
\hline $\mathrm{L} 40 \Delta \mathrm{G}$ & 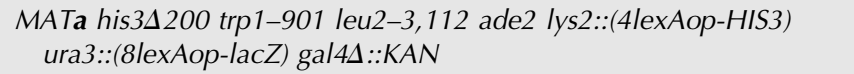 & $\begin{array}{l}\text { Fromont-Racine } \\
\text { et al. (2000) }\end{array}$ \\
\hline BY4741 & 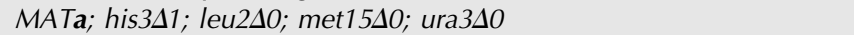 & Euroscarf \\
\hline YRG-C21-13myc & 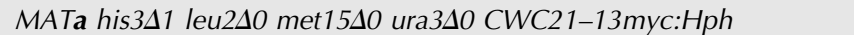 & This work \\
\hline YRG-C21AL & 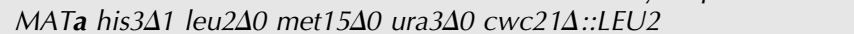 & This work \\
\hline Y16848-isy $1 \Delta$ & 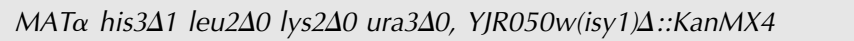 & Euroscarf \\
\hline YRGC21 $2 / 11 \Delta$ & 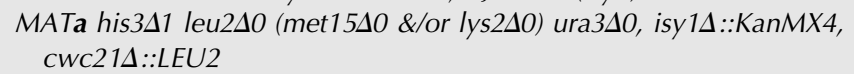 & This work \\
\hline
\end{tabular}


TABLE 2. Plasmids used in this work

\begin{tabular}{lll}
\hline Plasmid & \multicolumn{1}{c}{ Description } & Source/reference \\
\hline pBTM116 & $2 \mu$, TRP1, lexA(1-202)-BD & S Fields (unpubl.) \\
pBTM116-Prp8p(253-543) & pBTM116/LexA-Prp8(253-543) & This work \\
pACTII(st) & $2 \mu$, LEU2, Gal4-AD & Fromont-Racine et al. (1997)) \\
pACTII(st)-Cwc21 & $2 \mu$, LEU2, Gal4-AD-Cwc21 (full length) & This work \\
pACTII(st)-Snu114 & $2 \mu$, LEU2, Gal4-AD-Snu114 (full length) & This work \\
pRS423-Met25 & $2 \mu$, HIS3, MET25 promoter, CYC1 terminator & Euroscarf; Mumberg et al. (1994) \\
pRS413-Met25 & Cen, HIS3, MET25 promoter, CYC1 terminator & Euroscarf; Mumberg et al. (1994) \\
pFA6a-13myc-Hph & C-terminal tagging vector & This work \\
pRG423-pM-Cwc21-13myc & $2 \mu$, HIS3, pMET25-CwC21-13myc & This work \\
pRG413-pM-Cwc21-13myc & CEN, HIS3, pMET25-Cwc21-13myc & This work \\
pM-21M-R71D & CEN, HIS3, pMET25-Cwc21-R71D-13myc & This work \\
pM-21M-H67A & CEN, HIS3, pMET25-Cwc21--H67A-13myc & This work \\
pM-21M- I73A & CEN, HIS3, pMET25-CwC21-173A-13myc & This work \\
pRG423-pM-N-SRRM2-13myc & $2 \mu$, HIS3, pMET25-SRRM2(1-159)-13myc & This work \\
pDONR 221 & Gateway, entry vector & Invitrogen \\
pDEST 15 & Gateway, N-terminal GST & Invitrogen \\
GST-SRRM2 (1-159) & Modified from GST-SRm300 (Blencowe et al. 2000) & This work \\
pDEST 17 & Gateway, N-terminal His & Invitrogen \\
\hline
\end{tabular}

\section{Yeast protein immunoprecipitations}

We followed the same protocol as above except that after three washes in NTN buffer, $0.5 \mu \mathrm{L}$ of c-myc 9E11 X Trans cruz (Santa Cruz Biotechnology) were coupled to Protein A-Sepharose CL-4B beads (GE Healthcare) in $300 \mu \mathrm{L}$ of NTN buffer for $1 \mathrm{~h}$ with endover-end rotation. Following $45 \mathrm{~min}$ with blocking solution (containing $100 \mu \mathrm{g} / \mathrm{mL}$ each of tRNA, BSA, Glycogen) the beads were washed three times with NTN buffer and once in X1 IP ${ }_{150}$, then we followed the above protocol.

\section{BS $^{3}$ cross-linking}

Approximately $20 \mu \mathrm{g}$ of each protein were mixed in a final volume of $60 \mu \mathrm{L}$ in $\mathrm{X} 1 \mathrm{IP}_{150}$ for $1 \mathrm{~h}$ at $4^{\circ} \mathrm{C}$. BS ${ }^{3} / \mathrm{DMSO}$ solutions from $1 \mathrm{mM}$ upward were added to the proteins for a further $2 \mathrm{~h}$. The reaction was stopped by addition of $1 \mu \mathrm{L}$ of $400 \mathrm{mM}$ ammonium hydrogen carbonate, and after 5 min proteins were immunoprecipitated using glutathione beads as above. Protein gels were stained with GelCode (Pierce), bands cut out, and analyzed by MALDI-TOF mass spectrometry.

\section{Microarray analysis and quantitative PCR}

The design of the microarray used in this study was as described previously (Kershaw et al. 2009), and the arrays were printed at the Division of Pathway Medicine, University of Edinburgh. The protocols used can be found at http://www.biology.ed.ac.uk/ research/groups/jbeggs/microarray/cwc21_isy1_37.

For the quantitative real-time PCR, a Roche transcriptor was used to produce cDNA according to the manufacturer's instructions. The primer design for reverse transcription of the lariat species was based on Vogel et al. (1997). The real-time PCR was performed with Invitrogen Express SybrGreen as per the manufacturer's instructions on a Stratagene Mx3005P. The data are presented in Supplemental Table S6 and at the above website.

\section{SUPPLEMENTAL MATERIAL}

Supplemental material can be found at http://www.rnajournal.org.

\section{POTENTIAL CONFLICT OF INTEREST DISCLOSURE}

The two-hybrid screens were performed by the company Hybrigenics S.A. as a collaboration within the RNOMICS project.

\section{ACKNOWLEDGMENTS}

We are indebted to Ben Blencowe for communicating data prior to publication, for helpful comments on this manuscript, and for generously facilitating the copublication of our related papers. We thank Laurence Decourty, Christophe Malabat, and Cosmin Saveanu (Institut Pasteur), who performed the GIM screen, and Patrizia Fabrizio for providing excellent Snu114p antibodies This work was funded by Wellcome Trust grant 067311 and European Commission funding for the European Framework Programme V RNOMICS project and the European Framework Programme 6 Network of Excellence EURASNET.

Received August 31, 2009; accepted September 15, 2009.

\section{REFERENCES}

Abelson J. 2008. Is the spliceosome a ribonucleoprotein enzyme? Nat Struct Mol Biol 15: 1235-1237.

Abovich N, Rosbash M. 1997. Cross-intron bridging interactions in the yeast commitment complex are conserved in mammals. Cell 89: 403-412.

Achsel T, Ahrens K, Brahms H, Teigelkamp S, Lührmann R. 1998. The human U5-220kD protein (hPrp8) forms a stable RNA-free complex with several U5-specific proteins, including an RNA unwindase, a homologue of ribosomal elongation factor EF-2, and a novel WD-40 protein. Mol Cell Biol 18: 6756-6766. 
Bessonov S, Anokhina M, Will CL, Urlaub H, Lührmann R. 2008. Isolation of an active step I spliceosome and composition of its RNP core. Nature 452: 846-850.

Blencowe BJ, Issner R, Kim J, McCaw P, Sharp PA. 1995. New proteins related to the Ser-Arg family of splicing factors. RNA 1: 852-865.

Blencowe BJ, Issner R, Nickerson JA, Sharp PA. 1998. A coactivator of pre-mRNA splicing. Genes \& Dev 12: 996-1009.

Blencowe BJ, Bauren G, Eldridge AG, Issner R, Nickerson JA, Rosonina E, Sharp PA. 2000. The SRm160/300 splicing coactivator subunits. RNA 6: 111-120.

Boon KL, Norman CM, Grainger RJ, Newman AJ, Beggs JD. 2006. Prp8p dissection reveals domain structure and protein interaction sites. RNA 12: 198-205.

Brenner TJ, Guthrie C. 2005. Genetic analysis reveals a role for the C terminus of the Saccharomyces cerevisiae GTPase Snu114 during spliceosome activation. Genetics 170: 1063-1080.

Burckin T, Nagel R, Mandel-Gutfreund Y, Shiue L, Clark TA, Chong JL, Chang TH, Squazzo S, Hartzog G, Ares M Jr. 2005. Exploring functional relationships between components of the gene expression machinery. Nat Struct Mol Biol 12: 175-182.

Butcher SE. 2009. The spliceosome as ribozyme hypothesis takes a second step. Proc Natl Acad Sci 106: 12211-12212.

Ceron J, Rual JF, Chandra A, Dupuy D, Vidal M, van den Heuvel S. 2007. Large-scale RNAi screens identify novel genes that interact with the $C$. elegans retinoblastoma pathway as well as splicingrelated components with synMuv B activity. BMC Dev Biol 7: 30.

Chan SP, Kao DI, Tsai WY, Cheng SC. 2003. The Prp19p-associated complex in spliceosome activation. Science 302: 279-282.

Chen CH, Yu WC, Tsao TY, Wang LY, Chen HR, Lin JY, Tsai WY, Cheng SC. 2002. Functional and physical interactions between components of the Prp19p-associated complex. Nucleic Acids Res 30: $1029-1037$.

Collins CA, Guthrie C. 2000. The question remains: Is the spliceosome a ribozyme? Nat Struct Biol 7: 850-854.

Copic A, Dorrington M, Pagant S, Barry J, Lee MCS, Singh I, Hartman JL IV, Miller EA. 2009. Genomewide analysis reveals novel pathways affecting endoplasmic reticulum homeostasis, protein modification and quality control. Genetics 182: 757769.

Dahan O, Kupiec M. 2002. Mutations in genes of Saccharomyces cerevisiae encoding pre-mRNA splicing factors cause cell cycle arrest through activation of the spindle checkpoint. Nucleic Acids Res 30: 4361-4370.

Decourty L, Saveanu C, Zemam K, Hantraye F, Frachon E, Rousselle JC, Fromont-Racine M, Jacquier A. 2008. Linking functionally related genes by sensitive and quantitative characterization of genetic interaction profiles. Proc Natl Acad Sci 105: 5821-5826.

Dix I, Russell C, Yehuda SB, Kupiec M, Beggs JD. 1999. The identification and characterization of a novel splicing protein. RNA 5: 360-368.

Dix I, Russell CS, O’Keefe RT, Newman AJ, Beggs JD. 1998. ProteinRNA interactions in the U5 snRNP of Saccharomyces cerevisiae. RNA 4: 1675-1686.

Edgar RC. 2004. MUSCLE: Multiple sequence alignment with high accuracy and high throughput. Nucleic Acids Res 32: 1792-1797.

Finn RD, Tate J, Mistry J, Coggill PC, Sammut SJ, Hotz HR, Ceric G, Forslund K, Eddy SR, Sonnhammer EL, et al. 2008. The Pfam protein families database. Nucleic Acids Res 36: D281-D288.

Fromont-Racine M, Rain JC, Legrain P. 1997. Toward a functional analysis of the yeast genome through exhaustive two-hybrid screens. Nat Genet 16: 277-282.

Fromont-Racine M, Mayes AE, Brunet-Simon A, Rain JC, Colley A, Dix I, Decourty L, Joly N, Ricard F, Beggs JD, et al. 2000. Genomewide protein interaction screens reveal functional networks involving Sm-like proteins. Yeast 17: 95-110.

Fromont-Racine M, Rain JC, Legrain P. 2002. Building proteinprotein networks by two-hybrid mating strategy. Methods Enzymol 350: $513-524$.
Grainger RJ, Beggs JD. 2005. Prp8 protein: At the heart of the spliceosome. RNA 11: 533-557.

Hausmann S, Zheng S, Costanzo M, Brost RL, Garcin D, Boone C, Shuman S, Schwer B. 2008. Genetic and biochemical analysis of yeast and human cap trimethylguanosine synthase: Functional overlap of 2,2,7-trimethylguanosine caps, small nuclear ribonucleoprotein components, pre-mRNA splicing factors, and RNA decay pathways. J Biol Chem 283: 31706-31718.

Hertel KJ, Graveley BR. 2005. RS domains contact the pre-mRNA throughout spliceosome assembly. Trends Biochem Sci 30: 115-118.

Kershaw CJ, Barrass JD, Beggs JD, O'Keefe RT. 2009. Mutations in the U5 snRNA result in altered splicing of subsets of pre-mRNAs and reduced stability of Prp8. RNA 15: 1292-1304.

Khanna M, Van Bakel H, Tang X, Calarco C, Babak T, Guo G, Emili A, Greenblatt JF, Hughes TR, Krogan NJ, et al. 2009. A systematic characterization of Cwc21, the yeast ortholog of the human spliceosomal protein SRm300. RNA(this issue). doi: 10.1261/rna.1790509.

Konarska MM. 2008. A purified catalytically competent spliceosome. Nat Struct Mol Biol 15: 222-224.

Konarska MM, Vilardell J, Query CC. 2006. Repositioning of the reaction intermediate within the catalytic center of the spliceosome. Mol Cell 21: 543-553.

Krogan NJ, Cagney G, Yu H, Zhong G, Guo X, Ignatchenko A, Li J, Pu S, Datta N, Tikuisis AP, et al. 2006. Global landscape of protein complexes in the yeast Saccharomyces cerevisiae. Nature 440: 637-643.

Kuhn AN, Brow DA. 2000. Suppressors of a cold-sensitive mutation in yeast U4 RNA define five domains in the splicing factor Prp8 that influence spliceosome activation. Genetics 155: 1667-1682.

Kuhn AN, Reichl EM, Brow DA. 2002. Distinct domains of splicing factor Prp8 mediate different aspects of spliceosome activation. Proc Natl Acad Sci 99: 9145-9149.

Lee YJ, Lackner LL, Nunnari JM, Phinney BS. 2007. Shotgun crosslinking analysis for studying quaternary and tertiary protein structures. J Proteome Res 6: 3908-3917.

Liu S, Rauhut R, Vornlocher HP, Lührmann R. 2006. The network of protein-protein interactions within the human U4/U6•U5 tri-snRNP. RNA 12: 1418-1430.

Long JC, Caceres JF. 2009. The SR protein family of splicing factors: Master regulators of gene expression. Biochem J 417: 15-27.

Longman D, McGarvey T, McCracken S, Johnstone IL, Blencowe BJ, Caceres JF. 2001. Multiple interactions between SRm160 and SR family proteins in enhancer-dependent splicing and development of C. elegans. Curr Biol 11: 1923-1933.

Longtine MS, McKenzie A 3rd, Demarini DJ, Shah NG, Wach A, Brachat A, Philippsen P, Pringle JR. 1998. Additional modules for versatile and economical PCR-based gene deletion. Yeast 14: 953961.

Luz Ambrosio D, Lee JH, Panigrahi AK, Nguyen TN, Cicarelli RM, Gunzl A. 2009. Spliceosomal proteomics in Trypanosoma brucei reveal new RNA splicing factors. Eukaryot Cell 8: 990-1000.

Mefford MA, Staley JP. 2009. Evidence that U2/U6 helix I promotes both catalytic steps of pre-mRNA splicing and rearranges in between these steps. RNA 15: 1386-1397.

Miller JP, Lo RS, Ben-Hur A, Desmarais C, Stagljar I, Noble WS, Fields S. 2005. Large-scale identification of yeast integral membrane protein interactions. Proc Natl Acad Sci 102: 12123-12128.

Monteiro PT, Mendes ND, Teixeira MC, d'Orey S, Tenreiro S, Mira NP, Pais H, Francisco AP, Carvalho AM, Lourenco AB, et al. 2008. YEASTRACT-DISCOVERER: New tools to improve the analysis of transcriptional regulatory associations in Saccharomyces cerevisiae. Nucleic Acids Res 36: D132-D136.

Mumberg D, Muller R, Funk M. 1994. Regulatable promoters of Saccharomyces cerevisiae: Comparison of transcriptional activity and their use for heterologous expression. Nucleic Acids Res 22: $5767-5768$

Ohi MD, Link AJ, Ren L, Jennings JL, McDonald WH, Gould KL. 2002. Proteomics analysis reveals stable multiprotein complexes in both fission and budding yeasts containing Myb-related Cdc5p/ 
Cef1p, novel pre-mRNA splicing factors, and snRNAs. Mol Cell Biol 22: 2011-2024.

Pleiss JA, Whitworth GB, Bergkessel M, Guthrie C. 2007. Rapid, transcript-specific changes in splicing in response to environmental stress. Mol Cell 27: 928-937.

Schwer B, Guthrie C. 1991. PRP16 is an RNA-dependent ATPase that interacts transiently with the spliceosome. Nature 349: 494-499.

Schwer B, Guthrie C. 1992. A conformational rearrangement in the spliceosome is dependent on PRP16 and ATP hydrolysis. EMBO J 11: 5033-5039.

Sharon M, Robinson CV. 2007. The role of mass spectrometry in structure elucidation of dynamic protein complexes. Annu Rev Biochem 76: 167-193.

Shea JE, Toyn JH, Johnston LH. 1994. The budding yeast U5 snRNP Prp8 is a highly conserved protein which links RNA splicing with cell cycle progression. Nucleic Acids Res 22: 5555-5564.

Sinz A. 2006. Chemical cross-linking and mass spectrometry to map three-dimensional protein structures and protein-protein interactions. Mass Spectrom Rev 25: 663-682.

Small EC, Leggett SR, Winans AA, Staley JP. 2006. The EF-G-like GTPase Snu114p regulates spliceosome dynamics mediated by Brr2p, a DExD/H box ATPase. Mol Cell 23: 389-399.

Smith DJ, Query CC, Konarska MM. 2008. 'Nought may endure but mutability': Spliceosome dynamics and the regulation of splicing. Mol Cell 30: 657-666.

Staley JP, Guthrie C. 1998. Mechanical devices of the spliceosome: Motors, clocks, springs, and things. Cell 92: 315-326.

Strausberg RL, Feingold EA, Grouse LH, Derge JG, Klausner RD, Collins FS, Wagner L, Shenmen CM, Schuler GD, Altschul SF, et al. 2002. Generation and initial analysis of more than 15,000 full-length human and mouse cDNA sequences. Proc Natl Acad Sci 99: 16899-16903.

Tsai WY, Chow YT, Chen HR, Huang KT, Hong RI, Jan SP, Kuo NY, Tsao TY, Chen CH, Cheng SC. 1999. Ceflp is a component of the Prp19p-associated complex and essential for pre-mRNA splicing. $J$ Biol Chem 274: 9455-9462.
Valadkhan S, Manley JL. 2009. The use of simple model systems to study spliceosomal catalysis. RNA 15: 4-7.

van Nues RW, Beggs JD. 2001. Functional contacts with a range of splicing proteins suggest a central role for Brr2p in the dynamic control of the order of events in spliceosomes of Saccharomyces cerevisiae. Genetics 157: 1451-1467.

Villa T, Guthrie C. 2005. The Isylp component of the NineTeen complex interacts with the ATPase Prp16p to regulate the fidelity of pre-mRNA splicing. Genes \& Dev 19: 1894-1904.

Vogel J, Hess WR, Borner T. 1997. Precise branch point mapping and quantification of splicing intermediates. Nucleic Acids Res 25: 2030-2031.

Wahl MC, Will CL, Lührmann R. 2009. The spliceosome: Design principles of a dynamic RNP machine. Cell 136: 701718.

Waterhouse AM, Procter JB, Martin DM, Clamp M, Barton GJ. 2009. Jalview Version 2-a multiple sequence alignment editor and analysis workbench. Bioinformatics 25: 1189-1191.

Wefing S, Schnaible V, Hoffmann D. 2006. SearchXLinks. A program for the identification of disulfide bonds in proteins from mass spectra. Anal Chem 78: 1235-1241.

Wilmes GM, Bergkessel M, Bandyopadhyay S, Shales M, Braberg H, Cagney G, Collins SR, Whitworth GB, Kress TL, Weissman JS, et al. 2008. A genetic interaction map of RNA-processing factors reveals links between Sem1/Dss1-containing complexes and mRNA export and splicing. Mol Cell 32: 735-746.

Wilson TJ, Lilley DM. 2009. Biochemistry. The evolution of ribozyme chemistry. Science 323: 1436-1438.

Yoshimoto H, Saltsman K, Gasch AP, Li HX, Ogawa N, Botstein D, Brown PO, Cyert MS. 2002. Genome-wide analysis of gene expression regulated by the calcineurin/Crzlp signaling pathway in Saccharomyces cerevisiae. J Biol Chem 277: 31079-31088.

Zagranichnaya TK, Wu X, Danos AM, Villereal ML. 2005. Gene expression profiles in HEK-293 cells with low or high storeoperated calcium entry: Can regulatory as well as regulated genes be identified? Physiol Genomics 21: 14-33. 

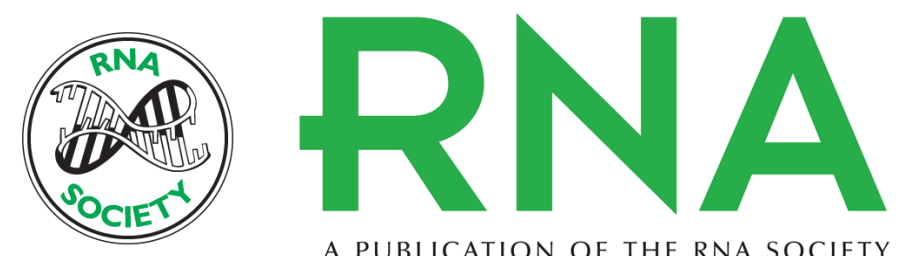

A PUBLICATION OF THE RNA SOCIETY

\section{Physical and genetic interactions of yeast Cwc21p, an ortholog of human SRm300/SRRM2, suggest a role at the catalytic center of the spliceosome}

Richard J. Grainger, J. David Barrass, Alain Jacquier, et al.

RNA 2009 15: 2161-2173 originally published online October 23, 2009

Access the most recent version at doi:10.1261/rna.1908309

Supplemental Material

Related Content

References

Open Access

License Freely available online through the RNA Open Access option. spliceosomal protein SRm300 May Khanna, Harm Van Bakel, Xinyi Tang, et al.

RNA December , 2009 15: 2174-2185

Articles cited in:

Freely available online through the RNA Open Access option.
http://rnajournal.cshlp.org/content/suppl/2009/10/20/rna.1908309.DC1

A systematic characterization of Cwc21, the yeast ortholog of the human

This article cites 68 articles, 27 of which can be accessed free at: http://rnajournal.cshlp.org/content/15/12/2161.full.html\#ref-list-1

http://rnajournal.cshlp.org/content/15/12/2161.full.html\#related-urls

Receive free email alerts when new articles cite this article - sign up in the box at the top right corner of the article or click here.
Service
Email Alerting Service

